\title{
Natural Resources and the Environment: Constitutional Challenges Facing Climate Change Policy in Canada
}

\author{
Yvonne Leung
}

The problem of anthropogenic climate change is arguably one of the foremost pressing issues facing the world today. With that, governments around the world have been working together to put forward binding targets and agreements to reduce greenhouse gas emissions in their respective jurisdictions. The most famous example of these multilateral efforts has culminated in the Kyoto Protocol, which was formally ratified by the Canadian government in 2002. However, despite this ratification, the federal government has failed to meet its reduction targets or legislate any substantial policy that would effectively regulate and reduce emissions. Indeed, rather than seeing emission levels fall, Canada's overall GHG emissions have increased substantially. ${ }^{1}$

There are various political and economic factors that contribute to the reason why Canada has failed to live up to its Kyoto targets and overall commitments to reduce its greenhouse gas emissions. However, this paper will focus on the constitutional obstacles that Canadian governments have faced in their attempts to implement Kyoto, as well as alternative policies to fight climate change.

This paper will begin by looking at the Kyoto Protocol and examining the jurisdictional conflicts that have resulted from its signing, as well as the problems that

\footnotetext{
${ }^{1}$ In 2006, Canada's GHG emissions increased by 27\% over 1990 levels. Mark Winfield and Douglas Macdonald, "The Harmonization Accord and Climate Change Policy: Two Case Studies in Federal-Provincial Environmental Policy," in Canadian Federalism: Performance, Effectiveness, and Legitimacy, eds. Herman Bakvis and Grace Skogstad (Don Mills: Oxford University Press, 2008) 278.
}

YVONNE LEUNG is in her final year of study the University of Toronto, majoring in Political Science and Canadian Studies. She is the founder and co-editor in chief of IMAGI(NATION)S: the Canadian Studies Undergraduate Journal at the University of Toronto. Outside of school, Yvonne is actively involved in both federal and provincial politics and is the Director of Communications of her local youth riding club. 
arise with attempts at its implementation. With that, I will then look at the possible constitutional conflicts between federal and provincial governments over greenhouse gas reduction policies. Ultimately, this paper aims to explore and understand how climate change policy in Canada is affected by jurisdictional tensions and how governments, both federal and provincial, should proceed in future to effectively tackle climate change.

\section{The Kyoto Protocol: Canada's Failure}

The Kyoto Protocol is a legal, binding international agreement, put forward by the United Nations Framework Convention on Climate Change and was signed by the federal government in 1998. As a signatory country, Canada is committed to "adopt national policies and take corresponding measures with the aim of reducing greenhouse gas emissions to 1990 levels. ${ }^{2}$ With that, Canada had committed itself to a $6 \%$ decrease of emissions by $2008 .^{3}$ However, as previously mentioned, Canada has failed to live up to its Kyoto targets and instead has seen a 27\% increase in emissions over 1990 levels. Moreover, Canadians continue to be one of the world's largest per capita emitters, with Canada emitting $2 \%$ of the world's GHG emissions but only accounting for $0.05 \%$ of the world's population. ${ }^{4}$

\section{The Environment: Concurrent Federal/Provincial Jurisdiction}

So, what accounts for this grand failure? There are numerous factors, but the most salient is a lack of effective policies and conflicting federal/provincial government agendas. Having a large country with a federal system of government can often make environmental legislation and implementation difficult, particularly when the Canadian constitution makes no direct reference to the environment and which order of government is responsible for matters pertaining to it. ${ }^{5}$ Indeed, both federal and provincial governments have legitimate claims to areas of environmental concern: with provinces

\footnotetext{
${ }^{2}$ Alastair R. Lucas, "Legal Constraints and Opportunities: Climate Change and the Law," in Hard Choices: Climate Change in Canada, eds. Harold Coward and Andrew J. Weaver (Waterloo: Wilfrid Laurier University Press, 2004) 181.

${ }^{3}$ Winfield and MacDonald, 278.

${ }^{4}$ Ibid.

${ }^{5}$ Glen Toner, "Contesting the Green: Canadian Environmental Policy at the Turn of the Century," in Environmental Politics and Policy in Industrialized Countries, ed. Uday Desai (MIT Press, 2002) 77-73.
} 
responsible for natural resources, local works and undertakings, property and civil rights, provincially-owned land and resources, as well as anything that can be understood as "matters of a local or private nature." 6 Meanwhile, the federal government has powers over seacoast and inland fisheries, federal land and waters, and a broad provision permitting the federal government to legislate anything in the interest of the "Peace, Order and Good Government" (POGG) of Canada. ${ }^{7}$

As a result, matters of the environment fall under both federal and provincial jurisdiction, and climate change, like many other issues of environmental concern, is a problem that does not heed to political borders. Consequently, the implementation of international treaties like Kyoto or even domestic policies aimed at GHG reduction, often will require a cooperative, collaborative effort from more than one level of government in order to be effective. Constitutionally speaking, only the federal government can sign on to international treaties. However, if the subject of the treaties fall under areas of provincial jurisdiction, it is up to the federal government to negotiate with the provinces the implementation of these treaties; otherwise, the federal government has no control over how or what the provinces do, as they are autonomous in their area of jurisdiction. ${ }^{8}$

\section{Natural Resources and Provincial Jurisdiction}

With that, a major challenge the federal government has faced when trying to implement GHG reduction policies, is that the main sources for Canada's emissions lie in areas of provincial jurisdiction. In a report to the United Nations, as obligated in its Kyoto commitments, the Canadian government found that the major sources for our emissions are in electricity and heat generation, fossil fuel production, mining, farm animals and waste. ${ }^{9}$ All of these sources are areas that fall under s.92 of the Constitution, which was emphasized when the provinces were assigned exclusive jurisdiction over the

\footnotetext{
${ }^{6}$ Ibid.

${ }^{7}$ Ibid.

8 Sylvia LeRoy and Jillian Frank, "Kyoto and the Constitution," in Fraser Forum (October 2002) 5.

9 Jeffrey Simpson, Mark Jaccard, and Nick Rivers, "Why a Warmer Canada is Bad News," in Hot Air:

Meeting Canada's Climate Change Problem (Toronto: McClelland and Stewart, 2007) 23-24.
} 
"development, conservation, and management of nonrenewable resources in the province, including forestry and hydroelectric facilities," in the 1982 Constitutional amendment. ${ }^{10}$

Moreover, the provinces are not only heavily responsible for the sources of greenhouse gas emissions; they are responsible for many of its possible solutions as well. A key component in GHG reduction is the protection of valuable carbon sinks, natural resources that absorb carbon out of the atmosphere. This includes lakes and oceans, as well as forests and agricultural land. ${ }^{11}$ Despite the fact that the vast majority of Canada's forests and green areas are in provincial jurisdiction, federal governments, both Liberal and Conservative, have been quick to announce safeguards of these natural resources. ${ }^{12}$

Furthermore, it is also important to recognize that Canada's economy is heavily dependent upon the exportation and exploitation of our natural resources. As a result, provinces can be very protective of their natural resources and what they might see as federal attempts to entrench on their authority to control them. ${ }^{13}$ With that, federal efforts to protect and conserve the natural environment can often interfere with a provincial government's own efforts to develop their Crown resources. ${ }^{14}$ The most obvious example of intergovernmental conflict in this area is demonstrated by the expanding oil and gas production in Canada's western provinces. In recent years, emissions in Alberta and Saskatchewan have grown the fastest and have the highest per-capita emissions of all the provinces. ${ }^{15}$ If Canada is to reduce its emissions to below 1990 levels, the reductions of these two provinces must be greater. For some, this means an unfair economic burden on these provinces, and with that, any federal suggestions to slow the growth of oil and gas industries have been met with fierce opposition from these governments. ${ }^{16}$

\section{Alberta v. Ottawa: Constitutional Challenges to Come?}

Indeed, one should also recall that the signing of the Kyoto Protocol was seen by many as a unilateral act of the federal government, which gave no warning or preparation

\footnotetext{
10 Toner, 73.

${ }^{11}$ Kathryn Harrison, "Passing the Environmental Buck," in New Trends in Canadian Federalism, $2^{\text {nd }}$ ed., eds. Francois Rocher and Miriam Smith (Toronto: Broadview Press, 2003) 337.

${ }^{12}$ LeRoy and Frank, 6.

${ }^{13}$ Harrison, 315.

${ }^{14}$ Ibid., 314.

${ }^{15}$ Simpson et al. 24

${ }^{16}$ Ibid., 25.
} 
for the provinces to deal with its ambitious $6 \%$ reduction target. ${ }^{17}$ Opposition to Kyoto has been most virulent in the oil and gas-producing province of Alberta, where days before Jean Chrétien's government introduced its Climate Change Plan for Canada in 2002, Ralph Klein's Alberta government put forward their own Climate Change and Emissions Management Act. ${ }^{18}$ This act reaffirmed the province's ownership of natural resources as protected in s.92(a) of the Constitution, which was further defined in the act to include both carbon dioxide and methane, claim property rights to carbon sinks, and quite possibly set the terms of reference for what could turn into a heated constitutional battle with Ottawa in the future. ${ }^{19}$

The act's assertion that carbon dioxide and methane are natural resources, which "are inextricably linked with the management of other renewable and non-renewable natural resources," is particularly relevant should the federal government attempt to regulate carbon emissions through what is known as a cap-and-trade system. Under capand-trade, the government sets a regulated, aggregate cap on emissions, and then allows firms to buy and sell "carbon credits" among themselves to meet their individual obligations, thus, creating a carbon market. ${ }^{20}$ Consequently, a national, emissions trading program that is imposed top-down has the potential to infringe upon provincial powers. Nevertheless, it is put forward by many environmentalists and economists alike that the most effective way to deal with climate change is through the implementation of a carbon-pricing policy, which a cap-and-trade system accomplishes. ${ }^{21}$

\section{POGG and Climate Change}

Moreover, the act also puts forward that carbon dioxide and methane, the two major greenhouse gases responsible for climate change, "are not toxic under atmospheric conditions." ${ }^{, 2}$ While this is factually true, this language fails to acknowledge the harm increased levels of carbon dioxide and methane have on the Earth's atmosphere and

\footnotetext{
${ }^{17}$ LeRoy and Frank, 5.

${ }^{18}$ Ibid.

${ }^{19}$ Sylvia LeRoy, “A Constitutional Firewall Against Kyoto,” in Fraser Forum (January 2003) 17.

${ }^{20}$ Simpson et al., "Dion and Harper: New Leaders, Discredited Ideas," 171-2.

${ }^{21}$ Ibid., 172.

${ }^{22}$ LeRoy, 18.
} 
climate. With that, the Alberta government is likely trying to avoid the possible future application of the federal government's extensive POGG powers, as demonstrated in the 1988 case of R. v Crown Zellerbach. In this case, the Supreme Court of Canada found that Parliament had the authority to regulate polluting activity that had extraprovincial effects. $^{23}$ Justice Gérard La Forest put forward that, "in an application of the doctrine of national dimensions of the general [POGG] power, Parliament may take steps to prevent activities in a province, such as dumping substances in provincial waters or emitting substances into the air, which pollute or have the potential to pollute...outside the province." 24 Consequently, R. v. Crown Zellerbach may support the case for federal regulation and legislation over GHG emissions.

The federal government's POGG powers are found in the opening of s.91 of the Constitution, where it states that the Government of Canada has the authority to enact laws for the "Peace, Order and good Government of Canada." ${ }^{25}$ In practice, the scope of these powers was limited as a residual power at first, but has gradually broadened its application to national emergencies and matters of a national concern, as well as matters of interprovincial concern or significance. ${ }^{26}$ Should the federal government attempt to implement Kyoto or any future climate change policies that will undoubtedly overlap with provincial jurisdiction, it may be possible for the federal government to assert these powers to override provincial opposition and constitutional challenges. However, given that climate change legislation affects large areas of provincial jurisdiction, such as natural resources and property/civil rights, the Supreme Court of Canada may be hesitant to give Parliament such sweeping power over the environment. ${ }^{27}$ Ultimately, looking at Alberta's climate change legislation, and recognizing that the federal government is under increasing pressure to put forward hard policy measures to reduce emissions, these conflicts may give us an idea of constitutional arguments to come. ${ }^{28}$

\footnotetext{
${ }^{23}$ Patrick J. Monahan, "Peace, Order and Good Government," in Constitutional Law, $3^{\text {rd }}$ Edition. (Toronto: Irwin Law, 2006) 271.

${ }^{24}$ R. v. Crown Zellerbach Canada Ltd., [1988] 1 S.C.R. 401.

${ }^{25}$ Monahan., 253.

${ }^{26}$ Ibid., 252.

${ }^{27}$ LeRoy and Frank, 6.

${ }^{28}$ LeRoy, 18.
} 


\section{Post-Kyoto: How Should Governments Take Action?}

With that in mind, after the ratification of Kyoto in 2002, multilateral negotiations between the federal government and the provinces broke down. These negotiations were plagued with ineffective, "lowest-common-denominator" agreements, caused by compromises made to appease all the parties involved. ${ }^{29}$ On the other hand, recognizing that provincial and federal governments will often have conflicting interests, particularly in regards to natural resources, the possibility of constitutional challenges is very real should the federal government decide to take a unilateral approach to climate change. These cases are often time-consuming, highly confrontational and do not encourage collaboration and cooperation where it is desperately needed. Thus, in order to avoid constitutional battles and court challenges, I feel the best way to deal with climate change in Canada is through intergovernmental consultations between federal and provincial governments.

However, in order to avoid the "lowest-common-denominator" outcomes of the past, a bilateral approach to GHG reduction may be the most desirable and harmonious method. Indeed, by spring 2006, the federal government had entered six bilateral agreements with the provinces, coupled with federal funding to help reduce emissions. ${ }^{30}$ While the agreements to do not stipulate specific plans of action, they do provide the provinces and federal government with a framework to build on for future negotiations. ${ }^{31}$

\section{Hard Policy Initiatives: Carbon Tax and Cap-and-Trade}

Moreover, while federal governments, both Liberal and Conservative, have been environmental laggards in regards to putting forward and implementing effective policies to reduce emissions, provincial governments have stepped up exponentially. In 2008, British Columbia introduced its own carbon tax, ${ }^{32}$ while Ontario and Quebec signed a Memorandum of Understanding on a cap-and-trade initiative. This MOU would "build on both provinces' participation in North American sub-national cap-and-trade systems,

\footnotetext{
${ }^{29}$ Winfield and Macdonald, 268.

${ }^{30}$ Ibid., 278.

31 Ibid.

${ }^{32}$ CBC News, "B.C. carbon tax kicks in on Canada Day,” June 30, 2008, http://www.cbc.ca/canada/british -columbia/story/2008/06/30/bc-carbon-tax-effective.html; accessed 20 February 2009.
} 
such as the Western Climate Initiative,"33 of which other provinces have also expressed similar intent or interest. While these policies have been modest and the negotiations have yet to bear fruit, it shows considerable progress and understanding that soft, voluntary government policies will not work to reduce emissions. Though perhaps optimistic, I feel that there is a real possibility for an interprovincial carbon trading system and am encouraged by the ongoing provincial negotiations.

Furthermore, with the election of President Barack Obama in the United States, the federal government has also recently indicated that it is interested in a unified North American cap-and-trade system. ${ }^{34}$ Provincial governments have long expressed their support for a continental emissions trading program, but have stated that intergovernmental cooperation is dependent on their being part of the consultation process. ${ }^{35}$ With that, it is evident that the provincial governments were not against the principles of Kyoto and the aim of reducing emissions; rather they simply would have liked to been consulted before the federal government set its targets. Given that the responsibility of implementation is ultimately within provincial jurisdiction, I think that provincial concern over unilateral federal climate change policy is legitimate.

Unfortunately, cap-and-trade systems are infamously bureaucratic and can take a long time to setup. For this reason, it would be ideal if the federal government exercised its extensive taxation powers to implement a carbon tax in the meantime. While provincial governments could lay claim to their authority over natural resources under a cap-and-trade system, the federal government, as stated in s.91(3) of the Constitution, has the authority to legislate "the raising of Money by any Mode or System of Taxation." An effective, economy-wide carbon tax would be entirely within the legislative authority of the Government of Canada; however, considering the outcome from the last federal election in 2008 , the current possibility of a carbon tax is very unlikely.

\footnotetext{
${ }^{33}$ Ontario, "First-Ever Joint Meeting of Ontario and Quebec Cabinets," Office of the Premier, June 2, 2008, http://www.premier.gov.on.ca/news/Product.asp?ProductID=2279; accessed 20 February 2009.

34 The Canadian Press, "Provinces express support for continental cap-and-trade talks at conference," Macleans.ca, February 17, 2009, http://www.macleans.ca/article.jsp?content=n021784A; accessed 21

February 2009.

35 Ibid.
} 


\section{Conclusion}

Ultimately, this paper has found that the competing interests and legislative jurisdiction of federal and provincial governments have strongly contributed to the inability of either orders of government to put forward hard policies to reduce greenhouse gas emissions. With that, effective climate change policies that address the reduction of GHG emissions, like carbon taxes and emissions trading, have only recently emerged in Canadian politics. However, given recent provincial developments, there is reason to be optimistic of further progress.

Moreover, while both federal and provincial governments have constitutional claims to legislative authority over issues of environmental concern, I feel it is in the best interest of Canadians for these governments to work together collaboratively rather than waste valuable time and resources over court challenges. Climate change is quite possibly one of the greatest threats facing humanity today and it is imperative that governments work quickly, not only for the interest of Canadians, but for the sake of the entire world. 


\section{Bibliography}

Canadian Press, The. "Provinces express support for continental cap-and-trade talks at conference." Macleans.ca. February 17, 2009.

http://www.macleans.ca/article.jsp?content $=$ n021784A. Accessed 21 February 2009.

CBC News. "B.C. carbon tax kicks in on Canada Day.” June 30, 2008. http://www.cbc.ca/canada/british-columbia/story/2008/06/30/bc-carbon-taxeffective.html. Accessed 20 February 2009.

Harrison, Kathryn. "Passing the Environmental Buck." In New Trends in Canadian Federalism, 2nd Edition, eds. Francois Rocher and Miriam Smith. Toronto: Broadview Press, 2003, p. 313-51.

LeRoy, Sylvia. “A Constitutional Firewall Against Kyoto.” In Fraser Forum, January 2003, p. 17-19.

LeRoy, Sylvia and Jillian Frank. "Kyoto and the Constitution." In Fraser Forum, October 2002, p. 5-6.

Lucas, Alastair R. "Legal Constraints and Opportunities: Climate Change and the Law." In Hard Choices: Climate Change in Canada, eds. Harold Coward and Andrew J. Weaver. Waterloo: Wilfrid Laurier University Press, 2004, p. 179-198.

Monahan, Patrick J. "Peace, Order and Good Government." In Constitutional Law, 3rd Edition. Toronto: Irwin Law, 2006, p. 253-77.

Ontario, "First-Ever Joint Meeting of Ontario and Quebec Cabinets." Office of the Premier. June 2, 2008. http://www.premier.gov.on.ca/news/Product.asp?ProductID=2279. Accessed 20 February 2009.

R. v. Crown Zellerbach Canada Ltd., [1988] 1 S.C.R. 401.

Simpson, Jeffrey, Mark Jaccard and Nick Rivers. Hot Air: Meeting Canada's Climate Change Problem. Toronto: McClelland and Stewart, 2007.

Toner, Glen. "Contesting the Green: Canadian Environmental Policy at the Turn of the Century." In Environmental Politics and Policy in Industrialized Countries, ed. Uday Desai. Cambridge: MIT Press, 2002, p. 77-73 
Winfield, Mark and Douglas Macdonald. "The Harmonization Accord and Climate Change Policy: Two Case Studies in Federal-Provincial Environmental Policy." In Canadian Federalism: Performance, Effectiveness, and Legitimacy, 2nd Edition, eds. Herman Bakvis and Grace Skogstad. Don Mills: Oxford University Press, 2008, p. 266-88. 